\title{
ist \\ Francis Bacon \\ e a questão da longevidade humana
}

\author{
Luciana ZATERKA
}

\begin{abstract}
茴
RESUMO

Desde sempre, o homem foi perseguido pelo desejo de imortalidade. Encontramos nas mais diferentes tradições culturais reflexões sobre a possibilidade da longevidade humana. Do ponto de vista filosófico, localizamos na obra de Francis Bacon a primeira sistematização moderna sobre o tema. O pensador inglês acredita que, diferentemente dos antigos, teria descoberto um método "para introduzir espíritos jovens em um corpo velho" e conjecturou na sua importante História da vida e da morte cenários possíveis para a regeneração física do homem. Nesse sentido, introduziu a possibilidade de o homem exercer o domínio sobre a natureza, império esse não só praticado sobre a natureza externa (o mundo natural), mas também sobre si próprio e, no limite, sobre o próprio corpo humano. Assim, Bacon teria aberto as portas para o sonho moderno de introdução de técnicas cada vez mais numerosas e eficazes de "melhoramento" dos indivíduos. Devemos prolongar a vida humana? Quais os "custos" desse prolongamento? A partir de então tais questões estão colocadas e permanecem mais atuais do que nunca.
\end{abstract}

PaLAVRaS-Ghave • Bacon. Longevidade. Imortalidade. Filosofia experimental. Século xvir.

Teoria da matéria.

\section{INTRODUÇÃO}

Talvez nenhum outro filósofo clássico nos faça questionar mais os fundamentos da nossa sociedade atual do que Francis Bacon (1561-1626). De fato, é impossível passar pelas linhas do Novum organum (1963 [1620]) ou do New Atlantis (1963 [1624]) sem pensar nas (terríveis) consequências de o homem ter assumido o domínio sobre a natureza e, nesse sentido, refletir sobre as relações intrínsecas entre ciência, técnica e poder. Desastres ambientais, problemas ecológicos, consumo exacerbado, desigualdades sociais, fim dos bens naturais, questões de bioética. E o interessante é que, apesar das evidentes melhorias que podemos observar graças ao desenvolvimento científico e tecnológico dos últimos dois séculos, tais como aumento da expectativa de vida, melhoria da saúde, diminuição do analfabetismo etc., o mal-estar da civilização permanece.

Nesse sentido, entre os vários questionamentos que a nossa sociedade contemporânea vivencia, existe um que foi objeto de estudo privilegiado por parte de Francis 
Bacon no início da modernidade: a questão do prolongamento da vida. Temos condições materiais e técnicas para prolongar a vida humana? Devemos prolongar a vida humana? É sabido que, a partir da filosofia baconiana, os homens de ciência do século XVII restabelecem ou reinstauram a plena autorização, contida no texto bíblico, para o homem exercer o domínio completo sobre a natureza, império esse não só praticado sobre a natureza externa ou o mundo natural, mas também sobre si próprio e, no limite, sobre o seu próprio corpo. É nesse contexto que pretendemos localizar a gênese histórico-conceitual dessa questão, para então refletirmos sobre alguns desdobramentos dessa problemática para a nossa sociedade atual. Dessa maneira, este artigo pretende apontar para algumas questões que permeiam a nossa contemporaneidade, afinal, se adicionamos anos a nossa vida, isso não quer dizer que adicionamos vida aos nossos anos. De fato, ao olharmos para os meios de comunicação contemporâneos, observamos uma preocupação constante com essa questão. Assim, por exemplo, um artigo recente publicado na Internet (cf. BBC Brasil, 2013) discute a preocupação que desde sempre acompanha os humanos: o processo que conduz à morte é inevitável ou pode ser interrompido ou mesmo revertido? Nesse mesmo sentido, podemos notar o aumento exacerbado nos últimos anos da quantidade de agências governamentais, hospitais, dietas miraculosas, suplementos alimentares, academias de ginástica, pesquisadores e médicos especialistas no cuidado com o fitness do corpo. E, por fim, no seu último relatório técnico a Organização das Nações Unidas (ONU) afirma que nos próximos 4,3 anos o número de pessoas com mais de 60 anos de idade será três vezes maior do que o atual. Os idosos representarão um quarto da população mundial projetada, ou seja, cerca de 2 bilhões de indivíduos. Porém, em muitos casos o aumento na quantidade de anos vividos não significa um aumento na qualidade de vida. Talvez por isso a questão do prolongamento da vida - se possível e se desejável - ganhou um lugar de destaque na nossa sociedade.

Nunca antes na história da humanidade os métodos mais ou menos científicos de prolongar a vida foram discutidos de maneira tão incessante em toda a sociedade como em nossos dias. O sonho do elixir da vida e da fonte da juventude é muito antigo, mas só assumiu uma forma científica - ou pseudocientífica - em nossos dias. A constatação de que a morte é inevitável está encoberta pelo empenho em adiá-la mais e mais com a ajuda da medicina e da previdência, e pela esperança de que isso talvez funcione (Elias, 1982, p. 56).

Uma primeira questão que devemos responder diz respeito à razão de localizarmos a gênese histórico-conceitual dessa problemática no universo seiscentista inglês, especialmente na obra de Bacon, pois desde a Antiguidade nomes importantes como 
Hipócrates (460 a.C.), Aristóteles (384 a. G.) e Galeno (13o d.G.) já se preocupavam com a questão da vida e da morte. Analisemos então rapidamente a posição dos antigos para entendermos por que localizamos a origem histórico-conceitual moderna dessa questão contemporânea na obra de Lorde Verulâmio.

\section{GÊNESE-HISTÓRICO CONGEITUAL DO PROBLEMA DA LONGEVIDADE HUMANA}

Existe uma opinião que perpassa hoje o senso comum, mas que foi constituída historicamente, que afirma a direta relação entre idade avançada e perda de vigor. Essa ideia possui uma razão de ser precisa. Se deixarmos de lado, por ora, as importantes diferenças entre as teorias médicas de Hipócrates e Galeno, notaremos entre os antigos uma premissa comum, ou seja, juventude significa vigor, senescência significa a perda dessa força. Esse vigor, essa potência ou força pode ser entendida como um "calor inato" ou um "fogo natural" intrínseco a cada ser vivo. Assim, por exemplo, no texto hipocrático Sobre a natureza do homem, lemos que "um homem é mais quente no primeiro dia de sua existência e mais frio no último" (Hipócrates, 1943, p. 36-7). Nesse mesmo sentido, durante muito tempo, médicos, escritores e filósofos operavam, mesmo que criticamente, com a metáfora da vida como um fogo e da senilidade como a extinção dessa chama. Galeno, por exemplo, afirma:

Se faço uma comparação entre as chamas do fogo e o calor dos animais, que eu não entendo muito bem, ou seja, como alguém pode comparar a destruição da matéria pelo fogo, com a criação da matéria pelo calor interno de animais. Pois o que se vê acontecer no caso do fogo não acontece no crescimento dos animais, que são, por sua vez, controlados pelo seu calor inato, que está constantemente se expandindo e carregando poderes diferentes do que aqueles que são os seus resultados diretos. Pois esse calor inato atrai comida para ele, controla a substância do corpo, é capaz de completá-lo, fazê-lo regenerar e dar-lhe uma forma definida. De maneira geral, ele funciona de uma maneira que é completamente oposta à aplicada pelas chamas de um fogo ao lidar com a substância que lhe é colocada por cima. O que a chama faria com a madeira (...)? Ou o que a chama iria manter da madeira a partir da sua destruição (...)? O calor inato faz com que os nossos corpos (...) formem canais. E desses canais alguns são capazes de conduzir nutrientes através deles, enquanto outros são usados para refrigeração e respiração, e para livrar-se de todos os resíduos (Galeno apud Jackson, 2012, p. 55). 
Galeno acredita, portanto, na existência de um calor inato intrínseco aos corpos vivos, nuclear, tanto para a compreensão de todas as alterações que ocorrem no corpo humano - nascimento, crescimento e declínio -, como para auxiliar na "absorção" da comida, na formação de canais que fornecem a refrigeração necessária, nutrientes e no descarte de resíduos. Mas pela citação acima notamos que a analogia com a chama possui um claro limite, pois o fogo comum opera no âmbito da destruição, enquanto o nosso calor inato é positivo, no sentido de que é visto como a principal fonte de todo crescimento e metabolismo.

Aristóteles também utiliza a metáfora da vida como fogo. Em De juventute et senectute, afirma:

Podemos observar duas maneiras em que o fogo deixa de existir, por exaustão e por extinção. O que é auto-causado chamamos de exaustão; o que é causado por opostos, extinção. Mas, na verdade, ambas as maneiras em que o fogo deixa de existir surgem a partir da mesma causa; pois quando há deficiência de nutrientes e o calor não pode obter nenhuma manutenção, o fogo enfraquece. (...) Tudo o que é vivo não pode existir sem a presença de calor natural (De juve, 5, 469b 21-25).

O Estagirita salienta aqui a importância do equilíbrio do calor inato. O objetivo é evitar, tanto quanto possível, a extinção ou o esgotamento dessa chama originária, e para tanto o corpo necessita de refrigeração constante e alimento. Nesse mesmo sentido, Galeno afirma que o corpo possui duas fontes de degeneração: uma intrínseca e espontânea; e outra extrínseca e acidental. A primeira é consequência do decaimento natural de nossa umidade vital; a segunda refere-se às doenças que podem surgir pelo embate com os fatores externos. É por isso que a velhice, nesse sentido, seria, antes de tudo, uma condição de secura. Todas as criaturas vivas estão destinadas ao ressecamento. É por isso que Galeno, em alguns textos, irá propor o umedecimento de suas partes como o principal remédio para o prolongamento da vida. E aqui chegamos a um ponto importante nesta discussão.

Quando os antigos falam em prolongamento da vida, eles não acreditam na possibilidade de a arte humana ter condições de interromper ou mesmo retardar a tendência natural de todos os corpos vivos, que é a morte. Em outras palavras, para os antigos seria impossível escapar do caminho natural que conduz do nascimento ao perecimento. Portanto, a possibilidade da longevidade, nesse contexto, diz respeito somente a uma "longevidade natural" mediada por meio da moderação de regimes, tais como o controle da alimentação, do sexo, das emoções e dos hábitos. Nesse sentido, há uma diferença importante entre adiar naturalmente a morte ao combater as doenças, ou preservar a saúde, e um prolongamento efetivo da vida por meio da arte médica e das técnicas humanas. 
Essa distinção permanece ao longo do Medievo. Avicena, por exemplo, afirma que a senilidade é natural e inevitável. Assim, embora possa variar de pessoa para pessoa, ela é um dado da natureza e, portanto, pertence ao âmbito do necessário. Avicena, nesse sentido, não acredita no uso de medicamentos para tentar a cura ou mesmo o retardamento da senescência. Prolongar a vida para além do que a natureza prescreve não é objeto da medicina, simplesmente porque tal objetivo é impossível. No limite, os fármacos só podem auxiliar a curar doenças que poderiam acelerar a morte, mas nunca seriam capazes de atuar para além dos limites da vida prescritos pela própria natureza para um determinado paciente. Essa tarefa pertence ao ramo do que os médicos antigos e medievais chamavam de higiene. ${ }^{\mathbf{1}}$

A arte de manter a saúde não é a arte de evitar a morte ou evitar ferimentos estranhos do corpo ou de assegurar o máximo de longevidade possível ao ser humano. Ela preocupa-se com duas outras coisas: (1) a prevenção do colapso putrefato; (2) a preservação da umidade inata de sua veloz dissipação e a manutenção em tal grau de força que o tipo original de constituição peculiar para a pessoa não deve mudar até mesmo no último momento de sua vida (Jackson, 2012, p. 83).

Assim, existe uma distinção importante entre adicionar tempo para além da determinação imposta pela natureza ou por Deus, ou seja, um prolongamento efetivo da vida, e curar uma doença pela arte médica no sentido de simplesmente adiar a morte inevitável. Nesse segundo caso, adicionamos tempo contra uma determinada doença que de outra forma teria encurtado a vida, mas não houve um alongamento quantitativo daquilo que já estava inscrito na ordem natural. Essa perspectiva é constituinte da tradição teológica cristã. "Naqueles dias adoeceu Ezequias mortalmente (...) Ouvi a tua oração, e vi as tuas lágrimas; eis que eu te sararei; ao terceiro dia subirás à casa do Senhor. E acrescentarei aos teus dias quinze anos (...)" (2, Reis, 20).

Até o surgimento da modernidade, em linhas gerais, observamos a permanência dessa dicotomia. Em outras palavras, há um claro limite - imposto por valores teológicos e religiosos - à possibilidade de a arte prolongar a vida humana. Todos os seres, até então, têm um prazo finito determinado que foi designado pela Providência. É por isso que ao longo da vida "o calor natural", "a umidade inata", "o sopro", "o archeu" de cada criatura diminui gradualmente, ${ }^{2}$ resultando na secura, no ressecamento, enfim na morte. Ora, nesse contexto, foi Deus ou a natureza quem fixou os nossos desígnios e,

1 Lembremos que os médicos renascentistas dividiam a parte prática de sua arte em dois ramos: o âmbito terapêutico, que dizia respeito à cura das doenças, e o higiênico que cuidava da preservação da saúde (cf. Mikkeli, 1999, p. 32-410) . 2 Pensadores como Roger Bacon, Marsilio Ficino e Paracelso, diferentemente da tradição que estamos analisando, irão fundamentar os seus respectivos princípios geradores da vida em uma fonte divina ou cósmica. 
portanto, a única maneira possível de prolongar a vida seria por meio da vontade e da graça divinas, isto é, pelo âmbito da religião, e não por meio das obras humanas. Bacon terá um lugar importante para a virada de perspectiva com relação a essa premissa.

\section{A gontribuição de Francis Bacon: longevidade prolongada}

Em um importante artigo sobre essa temática, Guido Giglioni escreveu que

se os antigos tinham preferido limitar-se a uma melhoria funcional do tempo de vida naturalmente atribuído a cada indivíduo, os modernos alimentaram o sonho audacioso de libertar-se das limitações impostas em suas vidas pela natureza. Enquanto os antigos tinham mantido a gradual não substituição da umidade radical e a imperfeição inevitável da nutrição, Bacon não excluía a possibilidade de transformar o processo cíclico, ainda que processo de vida inevitavelmente regressivo, em uma autorenovação perpétua do "fogo vestal”. Antecipando as ideias que levariam alguns dos membros da Royal Society a testar experimentos de transfusões de sangue, Bacon hipotetizou cenários possíveis de regeneração física. "Se fosse possível para os espíritos jovens serem colocados em um corpo velho", sugeriu ele, "é provável que essa grande roda pudesse colocar as rodas menores em movimento, e voltar o curso da natureza". Afinal, Bacon escreveu na Historia vitae et mortis que a idade é apenas uma "medida de tempo" convencional, que depende da interrelação de fatores internos e externos. A fé de Bacon nas perspectivas ilimitadas de implementações médicas e tecnológicas implicou uma redefinição radical do significado da ordem natural da vida. Uma nova compreensão da natureza progressivamente dissolveu o próprio conceito de condicionamento natural. $\mathrm{O}$ envelhecimento em si foi um desses condicionamentos naturais (Giglioni, 2005 , p. 14, grifo nosso).

Portanto, a grande virada imposta pela modernidade diz respeito à possibilidade, inimaginada até então, não só de o homem ser capaz de acelerar o curso ordinário da natureza, como na arte alquímica, por exemplo, mas de o homem ser capaz, de agora em diante, de produzir novas naturezas - naturezas artificiais ontologicamente semelhantes às naturezas originais. De fato, lembremos que vários dos filósofos seiscentistas irão utilizar referências às artes mecânicas em suas obras. Descartes, por exemplo, retomando a afirmação baconiana de uma filosofia operativa capaz de tornar o homem "como que senhor e possuidor da natureza", acrescenta, na famosa sexta parte do Discurso do método, que 
Frangis Bagon e a questão da longevidade humana

no lugar dessa filosofia especulativa que se ensina nas escolas, pode-se encontrar uma outra filosofia prática, pela qual, conhecendo a força e as ações do fogo, da água, do ar, dos astros, dos céus e de todos os outros corpos que nos cercam, tão distintamente como conhecemos os diversos ofícios de nossos artífices, poderíamos empregá-los da mesma maneira em todos os usos para os quais são adequados, e assim tornar-nos como que senhores e possuidores da natureza (Descartes, 1996, p. 61-2).

Ora, nesse novo contexto, a natureza deixará de ser sagrada e, portanto, inimitável. Em outras palavras, as coisas artificiais não diferem das coisas naturais pela forma ou pela essência, mas apenas pela causa eficiente; no limite, os movimentos artificiais não devem ser contrapostos aos naturais. O calor solar pode ser comparado ao fogo, o ouro natural presente na areia é idêntico ao artificialmente produzido nas fornalhas. A física terrestre será em breve equiparada à celeste. Assim, os homens de ciência não precisam mais temer a cólera divina por manipular, atormentar e alterar a natureza, pois manipular a obra divina é um de seus desígnios. Essa afirmação de uma não diversidade substancial entre os produtos da arte e os da natureza - presente em alguns dos maiores expoentes da nova filosofia natural - contrapõe-se radicalmente, como sabemos, à definição aristotélica da arte ou técnica, que apenas completa a obra da natureza ou imita-a em suas produções. Aqui as artes são vistas como adulteração e falsificação da natureza. Nesse sentido, notamos uma mudança na própria concepção de natureza na gênese da modernidade. A preferência demonstrada por homens como Leonardo, Galileu e Bacon pela mecânica - considerada a mais nobre das ciências por permitir, antes de mais nada, recolher os frutos da investigação na operação prática dos fenômenos da natureza - mostra uma virada de perspectiva com relação à tradição. Nessa "preferência" e nessa "volta", observamos uma verdadeira revolução cultural destinada a ter reflexos imprevistos, que está ligada a profundas transformações na vida econômica e social das sociedades europeias (cf. Rossi, 1989).

Nessa perspectiva, Bacon reformulou a concepção predominante de ciência, que era fundamentalmente contemplativa. Isso não significa que a ciência não realizasse observações empíricas, nem deixasse de fazer experimentos, porém a observação e a experimentação efetuadas, por exemplo, por Hipócrates e Galeno, não tinham como objetivo a transformação da natureza, e sim ajudá-la com as artes a realizar o que ela sozinha não teria forças para fazer. A técnica era a continuação da natureza e um auxílio a ela. Ao lado disso, não podemos esquecer que o aspecto contemplativo da ciência não poderia apoiar-se em ações, mas apoiava-se em escritos, nos livros das autoridades; Platão, Aristóteles, Plínio e Dioscórides eram alguns dos pilares do conhecimento da natureza da escolástica. Bacon propõe algo inovador: trocar os livros pelos fatos, a 
biblioteca pelo laboratório, e reunir o mundo teórico ao universo prático, julgando que o homem deve desvencilhar-se da metafísica escolástica e voltar-se para a natureza.

Para atingir o seu objetivo, Bacon propõe o seu Novum organum (1963 [1620]), ou seja, um novo instrumento que, ao dissecar os fenômenos da natureza pelo método $a$ posteriori ou indutivo, seria capaz de aproximar-se dos constituintes últimos dos corpos, na sua terminologia, das formas (cf. Zaterka, 2012). Salientemos, porém, que o experimento baconiano não é uma simples observação empírica, e sim uma intervenção sobre o curso da natureza, pois somente com essa intervenção - ou com o ato de atormentar a natureza - ela se manifestará da melhor maneira possível, ou seja, nas suas partes mais diminutas.

Entendo não apenas uma história da natureza independente e em liberdade quando é deixada no seu próprio curso e faz sua obra da sua própria maneira (...), mas muito mais uma [história da] natureza sob constrangimento e atormentada, quer dizer, quando pela arte e mão do homem ela é forçada a sair do seu estado natural e é constrangida e atormentada (...). A natureza das coisas se revela mais rapidamente quando submetida ao tormento da arte do que em sua liberdade natural (PW, p. 29).

Por acreditar que o homem perdeu o seu estado de inocência após o pecado original e, nesse sentido, perdeu a plena capacidade de conhecer e refletir o universo, Bacon propõe uma restauração do estado original por meio dessa nova concepção de ciência operativa.

O verdadeiro fim do conhecimento é a restituição e a restauração (em grande parte) do homem à soberania e ao poder que ele tinha no primeiro estágio da criação (porque quando ele for capaz de chamar as criaturas pelos seus verdadeiros nomes, poderá novamente comandá-las). Para falar com clareza e simplicidade, esse fim consiste na descoberta de todas as operações e possibilidades de operação: desde a imortalidade (se é possível) até a mais desprezada arte mecânica (IN, p. 222).

Assim, é por meio das obras humanas, das ciências, enfim, de um conhecimento voltado acima de tudo para o bem-estar dos homens, que poderemos reconquistar o domínio perdido sobre a natureza. Esse fundamento teológico e metafísico é importante para compreendermos o alcance do projeto baconiano. Segundo Bacon, Deus criou os homens sem imperfeições e, assim, a doença, o envelhecimento e, no limite, a morte foram adquiridos depois que Adão comeu o fruto proibido. De fato, em sua época ainda 
é a Bíblia que fornece os elementos primordiais de uma história unificada da natureza e da humanidade. Tal narrativa mostra que, se Adão e Eva não tivessem comido o fruto proibido, eles seriam literalmente eternos. De acordo com essa doutrina, deve-se considerar que antes do pecado original o homem era naturalmente, necessariamente imortal. Ora, após ter comido o fruto da árvore do conhecimento, ele foi expulso do paraíso. "O senhor Deus, pois, o lançou fora do jardim do Éden, para lavrar a terra, de que fora tomado" (Gênesis, 3, 16, 23). Nesse exato momento a criatura perde suas características divinas. Torna-se mortal, portanto, torna-se suscetível a inúmeras doenças do corpo e da alma. Porém, para Bacon, o fato de ele ter perdido a imortalidade não significa a perda de sua longevidade. Como um bom empirista, ou seja, como um homem de ciência que utiliza a experiência como instrumento metodológico fundamental, unindo argumentos lógicos, psicológicos e históricos, Bacon elabora uma história experimental da natureza por meio de um extenso inventário sobre os mais diversos fatores que podem interferir na vida dos animais e, sobretudo, na dos homens (cf. Bacon, 2007 [1623]). Tal registro tem como objetivo mostrar que a causa da longevidade humana não possui relação direta com o decreto divino, mas sim com causas naturais. Para tanto, então, mobiliza como argumento principal recuperar a "história" do dilúvio.

O filósofo inglês argumenta que, antes do dilúvio, os homens viviam por centenas de anos, e que essa idade caiu pela metade após a passagem de Noé. Segundo o relato bíblico, retomado por Bacon, Adão viveu 93o anos, Sete 912 anos, Cainan 910 anos e Matusalém 969 anos. Noé, por sua vez, viveu $95^{\circ}$ anos. Depois do dilúvio, entretanto, observamos uma queda na longevidade de tais patriarcas: Shem viveu 600 anos, Arpachade 4,38 anos, Selá 4,33 anos e Éber 4,64 anos.

Logo após o dilúvio essa longevidade cai pela metade somente para aqueles nascidos após esse evento, pois Noé, que nasceu antes dele, viveu tanto quanto os seus antepassados, e Shem viveu 600 anos. E, então, no prazo de três gerações após o dilúvio, a vida dos homens reduziu-se a um quarto de seu período original, ou seja, cerca de 200 anos (VM, p. 197).

Assim, a geração após Éber viveu 200 anos, como, por exemplo, Pelegue que morreu com 239 anos ou ainda Reú, Serugue, Naor e Terá que viveram por 239, 23o, 148 e 205 anos respectivamente. Ora, diferentemente de seus ancestrais, Abraão viveu somente 175 anos e Isaac 180 anos. A explicação corrente voltava-se novamente para argumentos contidos na Bíblia. Se levarmos, então, em consideração o relato do Gênesis, iremos lembrar que Deus inundou a Terra como um castigo para a maldade humana: 
E viu o Senhor que a maldade do homem se multiplicara sobre a Terra e que toda a imaginação dos pensamentos de seu coração era só má continuamente. Então arrependeu-se o Senhor de haver feito o homem sobre a Terra, e pesou-lhe em seu coração. E disse o Senhor: "Destruirei, de sobre a face da Terra, o homem que criei, desde o homem até o animal, até o réptil, e até a ave dos céus; porque me arrependo de os haver feito" (Gênesis, 6, 5-7).

Porém aqui devemos observar a perspectiva distinta e inovadora de Bacon acerca da doutrina, ao afirmar que a duração da vida não depende da graça divina ou de linhagem santa.

De acordo com a Sagrada Escritura, antes do dilúvio, os homens viviam por muitas centenas de anos. No entanto, nenhum dos patriarcas viveu até mil. Ora, a duração da vida não pode ser atribuída à graça ou a uma linhagem santa, pois antes do dilúvio contamos onze gerações de patriarcas, mas dos filhos de Adão por Caim apenas oito; de modo que os descendentes de Caim tiveram vida mais longa (VM, p. 197, grifo nosso).

A duração da vida não pode ser atribuída a um decreto de Deus; portanto, a providência divina não determina a longevidade humana, como a tradição afirmava. Assim, para Bacon, a causa da longevidade humana é absolutamente natural. De acordo com Jackson,

Bacon considera que, obviamente, a maior longevidade é uma dádiva e, porque os descendentes de Adão através do assassino e marginalizado Caim, viveram mais tempo do que os outros, ela não pode ter sido concedida aos patriarcas antediluvianos por Deus. Ao contrário, eles atingiram sua enorme longevidade pela natureza (Jackson, 2012, p. 280).

Para ilustrar sua perspectiva, utilizando argumentos históricos e científicos, Bacon fornece uma série de exemplos que demonstram a naturalidade do fenômeno da longevidade relativo à duração da vida humana. Avida longa ocorre com frequência em tempos de guerra, pois os homens, nessas épocas, fazem dietas simples e praticam exercícios com maior dedicação; por outro lado, a vida curta ocorre quando temos "maior civilização, boa vida e ociosidade". Contudo, Bacon observa que essas coisas "vem e vão" e ao longo de gerações não fazem, de fato, diferença. O que nos interessa nessa discussão é que o dilúvio pode ser comparado, no limite, a outro evento catastrófico ou extraordinário (um terremoto, um grande incêndio, um furacão), pois o que está sub- 
jacente à longevidade humana são causas naturais, ligadas ao curso ordinário da natureza. Temos aqui um ponto importante para o projeto baconiano que pretende, como vimos, reinstaurar ou restaurar o estado anterior à queda originária por meio de uma nova concepção de ciência operativa. Se a causa da diminuição da longevidade humana narrada na Bíblia é natural, seu remédio também deverá ser natural. Em outras palavras, será por meio da arte humana, isto é, com o auxílio de uma ciência eficaz e de uma prática médica indutiva, que o homem poderá atingir novamente a longevidade tão desejada e já vivenciada por alguns de nossos antepassados (cf. Jackson, 2012, p. 281).

Podemos, assim, notar claramente o fundamento metafísico-teológico presente na filosofia natural baconiana. É por isso que a questão da longevidade humana torna-se central nesse empreendimento filosófico. De fato, logo no início do exórdio de sua História da vida e da morte, o autor esclarece a razão de colocá-la em segundo lugar dentre as histórias naturais, e não mais em sexto, como havia mencionado na introdução da História natural e experimental. ${ }^{3}$

Embora tenha colocado a "História da vida e da morte" como a última das seis histórias [naturais] que planejei, decidi levá-la adiante e publicá-la em segundo lugar, tendo em vista a utilidade excepcional do assunto (...). Pois espero e desejo que ela trabalhe para o bem de muitos, e que os mais notáveis médicos (...) tornem-se servos da onipotência e misericórdia de Deus no prolongamento e renovação da vida do homem, especialmente se alcançado por meios seguros e convenientes (VM, p. 14,3).

Fica claro que o objetivo de prolongar a vida humana constitui uma das principais finalidades do programa baconiano como um todo. Tanto é assim que Graham Rees, comenta em seu prefácio que,

certo de que viveu em uma época ordenada pela Providência para o avanço do conhecimento, [Bacon] acreditou que a filosofia deveria melhorar as condições

3 A História da vida e da morte é uma das seis histórias naturais que constituem a História natural e experimental, concebida como a terceira parte da Grande instauração. As demais histórias naturais são a dos Ventos; a do Denso e raro; a dos Graves e leves; a da Simpatia e antipatia das coisas; a do Súlfur, mercúrio e sal. Apenas as duas primeiras foram publicadas em 1623; as outras foram editadas postumamente. As demais partes estão descritas no Plano da obra: Parte I: "As divisões das ciências" (Partitiones scientiarum); não elaborada, mas antecipada no Da proficiência e do progresso do conhecimento (The proficience and advancement of learning), de 1605; Parte II: "Novum Organum ou indicações acerca da interpretação da natureza" (Novum Organum, sive Indicia de Interpretatione Natura), de 1620; Parte IV: "A escada do intelecto" (Scala Intellectus); Parte V: "Os precursores ou antecipações da filosofia segunda" (Prodromi, sive Antecipationes Philosophiae Secundae); Parte VI: "Filosofia segunda ou ciência ativa" (Philosophia Secunda, sive Scientia Activa). Vários textos incompletos relativos a essas partes foram editados postumamente. 
materiais da raça humana e, então, em parte restabelecer a felicidade prelapsária. Ele assinalou o prolongamento da vida como o primeiro e mais alto objetivo da nova filosofia. A realização daquele sonho antigo iria cumprir um programa que propõe uma soteriologia material para este mundo (Rees, 2007, 1857, p. xlvi).

Ora, qual é então a proposta baconiana para retardar o processo da senescência? Como foi concebida essa salvação natural ou "soteriologia material"?

Diferentemente da tradição, que operava, como vimos, com qualidades vitais irredutíveis à matéria, tais como o archeu, o calor inato, a umidade natural etc., Bacon enfatiza o lugar das propriedades materiais da vida. Assim, nossa tarefa é compreender como foi concebido pelo autor o funcionamento do mecanismo da vida e da morte; antes, porém, é preciso conhecer a teoria da matéria que lhe dá fundamento, tal como proposta pelo filósofo inglês. Logo no início da obra, ele salienta a sua insatisfação com o estado do conhecimento médico e químico de sua época sobre a questão da longevidade.

Ora, é fácil aceitar isso como o maior bem, mas uma pesquisa para atingir os meios para alcançá-lo é difícil, ainda mais porque ele foi corrompido por falsas opiniões e informações infundadas. Pois o que a comunidade médica em geral fala sobre a umidade radical e o calor natural é enganoso, enquanto que o louvor extravagante amontoado nos medicamentos químicos só aumentam as esperanças dos homens para desiludi-los (VM, p. 145).

Por que o saber médico de sua época é enganoso? Pois os fatos não fornecem, segundo Bacon, suporte suficiente para a teoria da umidade radical ou do calor inato.

Eles olhavam para a morte como alguma coisa que não podia ser propriamente reparada, imaginando que havia alguma umidade primitiva e radical que não estava, de fato, reparada, mas que mesmo desde a infância tinha recebido uma espécie de adição artificial e não uma verdadeira reparação; e que com o tempo esta cresceu de maneira cada vez pior, até que finalmente terminou em nada (VM, p. 147).

Segundo Bacon, a senescência não está ligada à perda gradual de um calor natural inato, nem de um sopro vital, mas origina-se fundamentalmente em um processo degenerativo que afeta toda a matéria, não somente os corpos vivos. Notemos, assim, que Bacon remove das teorias médicas qualquer resíduo de uma substância vital, 
ao invés de enfatizar as propriedades inexplicáveis das propriedades vitais, anuncia um novo caminho para prolongar o curso da vida humana fundado em uma nova metafísica da matéria viva. A matéria é viva, afirma Bacon, porque regulada, estruturada e mantida por apetites primários. Os apetites não explicam somente todas as ações manifestas e reações da matéria, mas também a sua tendência latente à autopreservação e persistência por tempo indeterminado (Giglioni, 2005, p. 13o, grifo nosso).

De fato, em inúmeras obras, Bacon afirma que a matéria é composta por matéria tangível e por espíritos: "devemos investigar o quanto de espírito e o quanto de essência tangível há em todo corpo" (NO, p. 125). Ou ainda,

ora, uma vez que nada é mais certo e deve ser previsto, ou melhor, admitido como certo, como se fosse um postulado, que todo ser tangível daqueles que são conhecidos por nós (pois é difícil para a humanidade saber que tipo de condensação é típica dos corpos mais profundos no interior da Terra $)^{4}$ tem e contém, em virtude do refinamento contínuo confeccionado pela influência do Sol e dos corpos celestes, um espírito distribuído e investido nas partes mais grossas da matéria, misturado e fechado dentro de si. Ora, esse espírito não é certamente algum poder ou energia, ou coisa trivial, mas claramente um corpo tênue distribuído e investido nas partes mais grossas da matéria (VIJ, p. 319).

Até a publicação dessa obra, Bacon descrevia um único tipo de espírito presente em todos os corpos materiais. Porém, a partir de então, talvez por estar interessado pelo aprofundamento de questões ligadas à matéria viva, ele introduz um segundo tipo de espírito. O estudo da questão da longevidade doravante estará intimamente relacionado tanto à análise do mecanismo de funcionamento de tais espíritos, quanto à ligação entre tais espíritos e os fatores externos.

No História da vida e da morte (2007 [1623]), Bacon propõe uma metodologia inovadora, pois acredita que deve analisar as questões relativas à regeneração e ao prolongamento da vida pela perspectiva dos corpos inanimados. Contudo, lembremos que todos os corpos, portanto também os inanimados, possuem espíritos. "Em todos os seres vivos existem dois tipos de espíritos: os não vivos (spiritus mortuales) do tipo

4 É bom lembrarmos ainda que, para Bacon, o universo é um pleno finito e geocêntrico no qual a região acima da Lua contém inteiramente substâncias pneumáticas livres, e o centro da Terra é constituído somente de matéria tangível. É apenas na região abaixo da Lua e acima do centro da Terra que matéria tangível e espíritos se encontram e, portanto, interagem. De fato, no mundo sublunar não existem somente corpos pneumáticos livres - ar e fogo -, mas duas classes de substâncias pneumáticas (compostos de ar e chama) encerradas, envolvidas em uma matéria tangível. 
encontrado nas substâncias inanimadas, e os espíritos vitais (spiritus vitales)" (VM, p. 351). Qual é o lugar e o estatuto desses espíritos na teoria da matéria baconiana?5 Escutemos o pensador seiscentista. "Ora, esse espírito de que falo não é nem alguma virtude ou energia nem uma enteléquia ou algo sem valor, mas é claramente um corpo fino e invisível, alguma coisa com lugar e extensão" (VM, p. 346). Assim, os espíritos, antes de mais nada, são materiais; eles são sutis e sem peso, possuem apetites e impulsos, portanto, são os constituintes ativos da matéria, produzindo, assim, a maioria dos processos observáveis na natureza pelos nossos órgãos de sensação. Em contrapartida, para nossa percepção, a matéria tangível é passiva, fria e inerte e, então, deve ser compreendida como resistente às mudanças. Além dessa distinção entre espíritos e matéria tangível, Bacon propõe, como vimos, uma distinção entre os próprios espíritos. Enquanto os spiritus mortuales são considerados descontínuos, os spiritus vitales apresentam-se organizados e contínuos, e assim fluem por meio de canais que derivam de uma cavidade situada no cérebro; os spiritus mortuales não são quentes, enquanto os vitales são quentes, de modo que no primeiro predomina o componente aéreo, enquanto no segundo predomina o componente ígneo. Por fim, Bacon salienta que os espíritos vitais relutam frequentemente em abandonar os organismos que os limitam, pois fora deles não encontram nada que se assemelhe a eles, ao contrário dos espíritos inanimados, que desejam escapar dos corpos tangíveis por meio de seu componente aéreo, que o atrai para o ar ambiente.

O espírito, como uma chama suave, sempre predatório, conivente com o ar externo - ar que também suga e seca os corpos - finalmente destrói a estrutura do corpo e suas máquinas e instrumentos, e torna-os incapazes de fazer o trabalho de reparo. Esses são os verdadeiros caminhos da morte natural e que devemos considerar de modo diligente (VM, p. 147).

É interessante notar que a causa própria da dissolução dos corpos animados também se encontra nos spiritus mortuales, e não nos espíritos vitais. Mas, como os corpos vivos contêm necessariamente, além de espíritos vitais, também espíritos inanimados, os últimos finalmente prevalecem e todos os corpos entram em um processo de decadência. Bacon esclarece ainda que os espíritos vitais conferem consumpção ao corpo e, por conseguinte, tais corpos têm necessidade de alimentação.

5 Para Gerald Gruman, Bacon operaria no paradigma tradicional, não tendo assim trazido grandes inovações para a problemática da longevidade; no limite, teria simplesmente trocado o calor natural e a humidade inata pelos espíritos. Acreditamos que um estudo aprofundado sobre a teoria da matéria de Bacon mostre os problemas da interpretação de Gruman (cf. Gruman, 2003, p. 138-42). 
Assim, a pesquisa é dupla: de um lado na consumpção e destruição do corpo humano, e, de outro, na sua reparação ou bem-estar; com o objetivo de conter, tanto quanto possível, o primeiro, e fortalecer o último. A primeira delas diz respeito principalmente ao espírito e ao ar externo que causam a destruição; a segunda ao processo alimentar como um todo que traz bem-estar. Na medida em que a primeira começa, que se preocupa com a consumpção, tem muito em comum com o que acontece nos corpos inanimados. Pois o que o espírito inato (presente tanto nos corpos tangíveis vivos e não vivos), juntamente com o ar ambiente, fazem às coisas inanimadas, tentam fazer também para as animadas, embora aqui o espírito vital adicionado, em parte, abrande e bloqueie suas operações e, em parte, intensifique e os aumente em vão. Pois é perfeitamente óbvio que muitos corpos inanimados podem durar por um longo período sem reparo; mas os animados sem alimento e reparação rapidamente decompõem-se e morrem como o fogo. Assim, a pesquisa deve ser dupla: primeiro, considerando o corpo humano como algo inanimado e desnutrido; e, em segundo lugar, animado e nutrido (VM, p. 149).

É por acreditar então na importância dessa dupla perspectiva de análise que o filósofo inglês inicia a primeira seção histórica do História da vida e da morte descrevendo a "natureza dos duráveis", seção em que discute a maioria das causas que levam as substâncias, vivas ou não vivas, a perdurar no tempo. De modo geral, Bacon conclui aqui que as substâncias mais duráveis são duras ou oleosas, pois essas propriedades conseguem deter os espíritos inanimados, reduzindo a capacidade deles para escapar. Tanto é assim que, nas regras 15 e 16, afirma que "espíritos são detidos em um corpo de estrutura sólida, embora relutantemente"; e que "nas coisas oleosas e gordurosas, mesmo que elas não sejam tenazes, o espírito é mantido de bom grado" (VM, p. 361). Em seguida, depois de discutir inúmeros aspectos da questão, tais como a durabilidade das plantas, o problema da duração e brevidade da vida dos animais, algumas informações literárias para debater as variáveis em torno da expectativa de vida, o pensador aponta, em uma seção que contém cerca de 13.500 palavras ou 4,0\% da obra, os caminhos para prolongar a senilidade e adiar a morte em seres humanos. Para tanto, enuncia brevemente suas três intenções: "a proibição da consumpção, a realização de reparação, e a renovação do que tem envelhecido" (VM, p. 361). Essas intenções serão discutidas detalhadamente pelo filósofo em dez operações, isto é, possíveis procedimentos e tratamentos que atinjam as intenções mencionadas. ${ }^{6}$ Com relação à primeira

6 Para a primeira intenção, Bacon arrola quatro operações; para a segunda, outras quatro; e para a terceira, duas (cf. Zaterka, 2010, p. 127-40), que contém uma tradução parcial da obra aqui analisada. 
intenção, “a proibição da consumpção", por exemplo, Bacon fornece "receitas" para condensar os espíritos. Há basicamente quatro maneiras para atingir tal objetivo: concentrando-os com ópio ou outras substâncias semelhantes; esfriando-os com nitro; acalmando-os com vários fármacos orgânicos; e restringindo seus movimentos, por meio do sono, por exemplo. Assim, ópio, nitro, respirar ar frio, cheirar terra fresca e ainda manter os espíritos suavemente quentes, comendo alho, seriam procedimentos benéficos para todos. Por fim, adverte que as emoções violentas devem ser evitadas, uma vez que atenuam os espíritos; ao passo que as emoções moderadas, incluindo a tristeza, são úteis, pois fortificam e condensam tais espíritos: "aflição e tristeza destituídas de medo e sem muita angústia tendem a prolongar a vida, pois estas contraem os espíritos e são um tipo de condensação" (VM, p. 265).

O importante, de nosso ponto de vista, é que a causa da senescência, como entendida por Bacon, é um processo que ocorre tanto nos corpos animados como nos inanimados. Como ele mesmo afirma, a idade não é nada em si mesma, somente uma medida de tempo. Mas o processo que conduz à morte tem como causa os espíritos não vivos dos corpos, os quais, por um lado, absorvem a umidade do corpo e escapam dele, e, por outro, o ar ambiente que propicia a multiplicação desses espíritos inanimados. Ora, esse espírito que Bacon descreve aqui é o mortual, presente, como sabemos, em todos os corpos. Nesse sentido, a dessecação, que é parte constitutiva do envelhecimento, é um processo latente que merece, portanto, observações metódicas em todos os corpos existentes na natureza. Conhecendo, então, o mecanismo de tal funcionamento, Lorde Verulâmio conclui que temos a capacidade de introduzir nos nossos corpos, por exemplo, substâncias de natureza duráveis - duras ou oleosas - que terão a capacidade de deter os espíritos não vivos e, então, retardar o processo de senescência.

\section{O PROLONGAMENTO DA VIDA: UMA PEQUENA DIGRESSÃO}

Para nós interessa salientar que essa conclusão de Bacon aponta para uma perspectiva de alteração e manipulação do vivo, mediante técnicas e conhecimentos interventivos no âmbito da materialidade do humano, que teve como consequência abrir caminho para uma nova postura frente à questão da longevidade. $\mathrm{O}$ valor, a finalidade que estava inscrita na natureza, passa para o âmbito do humano. A técnica, antes um simples meio para auxiliar o bem-estar da humanidade, passa a ser, como moderna tecnologia, a própria finalidade.

Porém, devemos esclarecer um aspecto fundamental. Ao restaurar a plena autorização do homem para exercer o domínio sobre a natureza e também sobre si próprio, o projeto baconiano não o faz retirando do ser humano a sua dignidade de criatura pri- 
vilegiada, pois a própria investigação sobre a longevidade humana associa-se a sua função de "ministro e intérprete da natureza" (NO, p. 47), isto é, colabora com a providência divina no sentido de construir artes e técnicas humanas para o bem-estar da sociedade. Em outros termos, seu programa propicia subsídios para o desenvolvimento de uma ética científica de cunho social e a implementação de exigências e critérios de apreciação da investigação científica nos âmbitos econômico e político. Essas reflexões de cunho epistemológico e ético social instigam-nos a pensar nos desdobramentos e consequências que podemos extrair hoje dessa discussão. Na gênese históricoconceitual dessa problemática, observamos a diferença fundamental entre longevidade e saúde, quantidade e qualidade de vida, isto é, entre o adiamento da morte por meio de regimes e drogas e um prolongamento efetivo da vida. Hoje em dia possuímos meios técnicos suficientes para prolongar a vida humana, mas a pergunta que deveríamos formular é outra: devemos prolongar a vida humana? Por quê? Quais as consequências concretas (éticas, epistêmicas, socioeconômicas, políticas), seja no âmbito individual, seja no coletivo, dessa "nova velhice" humana?

Na gênese da modernidade, os homens vivenciaram a utopia de uma nova era, e pela primeira vez foi possível criar novas naturezas artificiais, de maneira antes impensável, e operar técnicas sobre os fenômenos da natureza, por meio da arte humana: novos fármacos, novas rotas marítimas, aumento da produção de alimentos por meio da fabricação de fertilizantes potentes, construções inéditas, a imprensa, a bússola, a pólvora. Agora, porém, em pleno século xxi, apesar de todos os avanços da ciência e da tecnologia, o mal-estar da civilização permanece mais vivo do que nunca. Se a resposta à pergunta acima - devemos prolongar a vida humana? - for afirmativa, que se levem em consideração tanto as consequências individuais como o princípio da dignidade da pessoa humana, quanto as coletivas, como, entre outras, o acesso público à saúde para todos. É inegável que tratamentos antes inimagináveis tornaram-se uma realidade cotidiana, criando uma grande possibilidade de cura de doenças, de realização de exames sofisticados, invenção de vacinas e remédios para as mais diversas doenças; implantes, transplantes, enxertos, próteses; seres portadores de órgãos artificiais; anabolizantes, vacinas, psicofármacos; estados artificialmente induzidos, como no coma ou na criogenia; clones e subespécies de organismos geneticamente modificados; enfim, seres artificiais que superam, localizada e parcialmente, as limitadas qualidades e as evidentes fragilidades dos seres humanos. Tudo isso melhorou a vida dos habitantes dos grandes centros urbanos, mas também é inegável que trouxe consequências às vezes não tão boas, como a possibilidade de tornar-se um doente refém de tratamentos experimentais prolongados, talvez revelados ao final inúteis para seu caso. O problema maior da vida prolongada por aparelhos e recursos farmacológicos é o entendimento sobre o que é obrigatório, opcional ou indevido proporcionar a esses 
indivíduos. E aqui voltamos para a dicotomia existente antes da época moderna, isto é, a distinção nuclear entre quantidade e qualidade de vida, entre o adiamento da morte e um prolongamento efetivo da vida. Suspender tratamentos não frutíferos não significa encurtar o tempo de vida, mas deixar de alongá-la artificial e inutilmente, muitas vezes maltratando o doente sem gerar qualquer benefício. Mesmo na perspectiva baconiana que acredita, como vimos, em uma concepção de longevidade prolongada, a eutanásia, por exemplo, é vista com bons olhos.

O ofício do médico não é somente restaurar a saúde, mas também mitigar as dores e tormentos das doenças; e não somente quando tal mitigação da dor (...) ajuda e conduz à recuperação, mas também quando, esvaindo-se toda a esperança de recuperação, serve somente para conseguir uma saída da vida mais fácil e justa (...). Em nossos tempos, os médicos fazem questão de escrúpulo e religião o estar junto do paciente quando ele está a morrer (...), em meu julgamento, os médicos devem adquirir habilidades e prestar atenção em como o moribundo pode deixar a vida mais fácil e silenciosamente. A isso eu chamo a pesquisa sobre eutanásia externa (euthanasia exteriori) ou morte fácil do corpo, a que se distingue da outra eutanásia que tem por objeto a preparação da alma (ad differentiam ejus Euthanasiae quae animae praeparationem respicit) (AS, p. 594-5).

Com Bacon, a eutanásia ganha uma nova acepção, já não se relaciona unicamente ao sentido etimológico grego eu (bom) e thanatos (morte), isto é, a boa morte, a morte fácil, não assistida, mas admite uma certa ação médica que pode auxiliar o enfermo a morrer de maneira mais fácil e tranquila. Descreve esse processo como euthanasia exteriori, a boa morte que vem de fora. Simultaneamente existe a boa morte "que vem de dentro", a morte calma e serena, quando a alma do paciente foi, aos poucos, preparada. Dessa maneira, nosso pensador aponta para limites claros e precisos sobre o prolongamento indefinido da vida: quando não há, de fato, esperança na recuperação de um moribundo, o melhor "é a morte fácil e justa". E não poderia ser diferente, pois a máxima baconiana "saber é poder" significa, sobretudo, que a atuação da ciência deve visar o bem-estar da humanidade e, então, as descobertas feitas pela ciência tem como objetivo facilitar a vida humana sobre a Terra. Contudo, ironicamente o problema encontrase exatamente no sucesso excessivo desse ideal e, portanto, nos seus desdobramentos.

A fórmula baconiana diz que saber é poder. No entanto, a realização dessa fórmula, no ápice de seu triunfo, tornou manifesta a dialética em que se envolve esse poder: o grau mais avançado de exploração técnica da natureza para sujeição desta à vontade de poder humana revela, sob o signo da iminente catástrofe ecoló- 
gica, sua insuficiência e sua autocontradição. Esta se apresenta sob a figura da perda de controle sobre si mesmo em que mergulha o programa baconiano, por sua incapacidade de proteger não somente o homem de si mesmo, mas também de proteger do homem a natureza e a própria natureza humana, tal como esta se revelou em sua essência até aqui. Essa dupla necessidade de proteção surge justamente por meio da extensão desmedida do poder alcançado no percurso do progresso técnico e da compulsão paralelamente crescente a seu emprego, que conduziu à espantosa impotência de pôr termos ao extensivo e previsível progresso destrutivo de si mesmo e de suas obras (Giacóia, 1999, p. 419).

Com efeito, a questão do prolongamento da vida e, no limite, a obtenção de um tipo de "imortalidade temporária" ou prolongamento indefinido por meios científicos e tecnológicos, é um assunto frequentemente debatido na atualidade, por exemplo, pelos adeptos do transhumanismo (movimento filosófico, sabemos, que incentiva a utilização da ciência e da tecnologia para superar as limitações humanas), com base na crença de que devemos implementar o uso racional da tecnologia para a melhoria da condição humana sempre para melhor. Apesar de soarem fantasiosos, os debates são signos da esperança no advento de uma utopia técnica que liberte o homem do envelhecimento, adoecimento e morte. Ao recuperar essas questões na obra de Bacon, o presente trabalho pretende lançar luz sobre a gênese desse processo, fornecendo elementos para um quadro referencial mais amplo sobre o tema (cf. Fressoz, 2012). Não obstante, cumpre mencionar que, nos dias de hoje, a gama de problemas suscitados pelo avanço tecnológico sequer poderia ser imaginada no nascimento da modernidade. A título de ilustração, muito se fala sobre o melhoramento genético de nossa espécie, mas isso levanta a questão de se tal melhoramento estender-se-á a todas as pessoas ou apenas à parcela economicamente mais privilegiada. Caso se efetive a segunda alternativa (a mais provável, diga-se de passagem), isso levaria à partição da espécie humana em duas, digamos "gene rich" e "gene poor", ou seja, aqueles que podem ter acesso e aqueles que não podem ter acesso às aplicações da genômica. ${ }^{7}$ Nesse caso, a visão utópica de uma humanidade livre de doenças genéticas transformar-se-ia em uma distopia na qual a desigualdade social estaria inscrita por meio da aplicação de tecnologias avançadas nos próprios corpos dos indivíduos. Uma crítica construtiva do pensamento utópico, com efeito, não pode prescindir de uma análise pormenorizada das consequências não antecipadas da tecnologia científica contemporânea.

7 Silver (2007), fala do uso das novas tecnologias genéticas para fazer duas linhagens de seres humanos: a gene rich (seres humanos geneticamente melhorados, especialmente com respeito à inteligência) e a gene poor (os geneticamente não melhorados). $\mathrm{O}$ autor ainda afirma que possivelmente os gene rich irão se reproduzir somente com outros genes de pessoas ricas e, assim, a desigualdade será cada vez mais perpetuada e estendida entre a população mundial. 


\section{Considerações finais}

A morte é uma das maiores inquietudes da condição humana, tendo demarcado esforços para o seu equacionamento ao longo da história do pensamento ocidental. Ainda antes do "nascimento" da filosofia notamos matizes diversos na compreensão dos problemas relativos à finitude humana, por exemplo, nas obras de Homero. Do ponto de vista filosófico, inúmeros pensadores trataram da questão. Platão, para quem a filosofia é exatamente uma longa meditação sobre a morte; Cícero e Montaigne, para quem filosofar é, acima de tudo, aprender a morrer; Heidegger, que viu na mortalidade humana a condição existencial por excelência; Hegel, que em sua importante Fenomenologia do espírito articula um discurso com vistas à superação da morte; Epicuro, Espinosa e Nietzsche, que, por diferentes razões, acreditam que a morte é uma meditação sobre a vida.

Vimos que para os antigos, especialmente para Aristóteles e Galeno, havia um claro limite à possibilidade de a arte humana prolongar a vida. $\mathrm{O}$ caminho fixado pela natureza era do âmbito do necessário e não poderia ser alterado. Talvez um olhar atento para essa tradição possa iluminar alguns dos debates atuais sobre essa problemática, no sentido de que sejam reconhecidos limites éticos à ação técnica humana. Até o advento da modernidade, curar uma doença que iria simplesmente encurtar a vida, por meio de medicamentos, regimes, mudança de hábitos era possível, mas seria inimaginável utilizar técnicas para a manutenção de doenças claramente terminais. A modernidade trouxe a possibilidade de o homem exercer um domínio não somente sobre a natureza, mas sobre o seu próprio corpo. Aqui abriu-se o caminho para a intervenção efetiva de técnicas fármaco - químicas no âmbito da materialidade do humano. Porém, devemos enfatizar que, como vimos, o projeto baconiano não retira do ser humano a sua dignidade de criatura privilegiada, pois a questão sobre a longevidade humana inscreve-se na sua função de "ministro da natureza", isto é, colabora com a providência divina no sentido de construir novas técnicas, sobretudo para o bem-estar de todos. Acreditamos que o problema está nos desdobramentos e desenvolvimentos dessa posição filosófica, que foi compreendida sem a sua dimensão ética, que estava ancorada fundamentalmente em princípios teológico-metafísicos. A negligência dessa dimensão e a mera consideração da possibilidade de um progresso sem limites das tecnologias e a invenção de tratamentos antes inimagináveis desde o início da modernidade, que era sem dúvida parte do projeto do Lorde Verulâmio, tornaram-se pouco a pouco um movimento autoteleológico, que tem por finalidade o desenvolvimento das tecnologias, sem a prudente avaliação de seus benefícios individuais e sociais. Perdendo-se, portanto, essa importante dimensão ética e social da ciência empírica e humanista pensada por Bacon. Hans Jonas nos alerta sobre as consequências do projeto baconiano. 
Bacon não poderia imaginar um paradoxo desse tipo: o poder engendrado pelo saber conduziria efetivamente a algo como um "domínio" sobre a natureza (ou seja, à sua superutilização), mas ao mesmo tempo a uma completa subjugação a ele mesmo. O poder tornou-se autônomo, enquanto sua promessa transformouse em ameaça e sua perspectiva de salvação, em apocalipse. Torna-se necessário agora, a menos que seja a própria catástrofe que nos imponha um limite, um poder sobre o poder - a superação da impotência em relação à compulsão do poder que se nutre de si mesmo na medida de seu exercício (Jonas, 1979, p. 236-7).

De fato, o homem passou a figurar entre os próprios objetos da técnica. O homo faber "aplica sua arte sobre si mesmo e habilita-se a refabricar inventivamente o inventor e confeccionador de todo o resto" (Jonas, 1979, p. 57). O prolongamento da vida, o controle do comportamento humano e a manipulação genética mostram esse avanço qualitativo na ação humana. Ora, esse mais recente uso da arte sobre a natureza desafia novas concepções éticas, que antes não precisavam ser colocadas, afinal os próprios fundamentos metafísico-teológico dos empreendimentos filosóficos modernos, como os de Bacon, forneciam a garantia para uma ética de cunho social.

Para lidar com o desejo de imortalidade, desenvolvemos ao longo dos últimos séculos técnicas complexas. Em outras palavras, a possibilidade humana de uma longevidade cada vez maior realimenta a utopia da vida eterna. Desde a modernidade, o ideal da imortalidade está sempre presente em suas expressões técnicas. Entretanto, o problema não é simplesmente o da possibilidade de aumentarmos ou não exponencialmente a duração de nossa vida, mas vivermos uma vida qualitativamente boa e principalmente digna. Que possamos, antes que seja tarde, resgatar, ou pelo menos, refletir sobre a dimensão ético-social introduzida pela ciência humanista tal como delineada por Francis Bacon.

Agradecimentos. Agradeço o apoio da Universidade Federal do ABC e do CNPq (Projeto n ${ }^{\circ} 4485^{25} / 2014$-3) para o desenvolvimento da presente pesquisa.

Luciana ZATERKA Centro de Ciências Naturais e Humanas, Universidade Federal do ABC, São Bernardo do Campo, Brasil. luciana.zaterka@ufabc.edu.br 


\section{ABSTRACT}

Human beings have always been captivated by the desire for immortality. Thus, in many different cultural traditions we find reflections on the possibility of human longevity. From a philosophical point of view, we locate in Francis Bacon's work the first modern systematic development of the issue. The English philosopher believes that, unlike the ancients, he discovered a method "to introduce young spirits into an old body" and, in his important History of Life and Death, conjectured scenarios for the physical regeneration of human beings. In line with this, he introduced the possibility of human beings exercising dominion over nature, where this domination is practiced not only on external nature, but also on themselves, indeed, on their own bodies. Bacon opened the door to the modern dream of increasingly numerous and effective techniques for the "improvement" of individuals: Must we extend human life? What are the "costs" of this extension? Since Bacon such questions have been raised, and now they remain more relevant than ever.

KEYWORds • Bacon. Longevity. Immortality. Experimental philosophy. Seventeenth century. Theory of matter.

\section{REFERÊNGIAS BIBLIOGRÁFICAS}

Adam, C. \& Tannery, P. (Ed.). Oeuvres de Descartes. Paris: Vrin, Centre National du Livre, 1995-1998. 11 v. (AT)

Aristóteles. On youth, old age, life and death, and respiration. In: Barnes, J. (Ed.). The complete works of Aristotle. Princeton: Princeton University Press, 1984. v. 1, p. 745-63. (De juve)

Bacon, F. Of the interpretation of nature. In: Spedding, J.; Lestie R. \& Heath, D. D. (Ed.). The works of Francis Bacon. Stuttgart/Bad-Cannstatt: Frommann/Holzboog, 1963 .v. 3, p. 217-52. (IN) . The plan of the work. In: Spedding, J.; Leslie R. \& Heath, D. D. (Ed.). The works of Francis Bacon. Stuttgart/Bad-Cannstatt: Frommann/Holzboog, 1963. v. 4, p. 22-33. (PW) . History of life and death. In: Spedding, J.; Leslie R. \& HeAth, D. D. (Ed.). The works of Francis Bacon.

Stuttgart/Bad-Cannstatt: Frommann/Holzboog, 1963 [1623]. v. 2, p. 91-226. (HVM) . Novum organum. In: Spedding, J.; Leslie R. \& Heath, D. D. (Ed.). The works of Francis Bacon. Stuttgart/Bad-Cannstatt: Frommann/Holzboog, 1963 [1620]. v. 4, p. 39-248. (NO)

. De augmentis scientiarum. In: Spedding, J.; Leslie R. \& Heath, D. D. (Ed.). The works of Francis Bacon. Stuttgart/Bad-Cannstatt: Frommann/Holzboog, 1963. v. 1, p. 415-837. (AS) . New Atlantis. In: Spedding, J.; Leslie R. \& Heath, D. D. (Ed.). The works of Francis Bacon. Stuttgart/ Bad-Cannstatt: Frommann/Holzboog, 1963 [1624].v. 3, p. 119-66.

. Historia vitae \& mortis. In: Rees, G. (Ed.). The Oxford Francis Bacon. Oxford/New York: Oxford University Press, 2007 [1623].v. 12, p. 14,1-377. (VM) . De vijs mortis. In: ReEs, G. (Ed.). The Oxford Francis Bacon. Oxford/New York: Oxford University Press, 2003 [1610].v. 6, p. 270-359. (VIJ)

Barnes, J. (Ed.). The complete works of Aristotle. Princeton: Princeton University Press, 1984. 2 v.

BBC Brasil. "Blitz da saúde" pode retardar envelhecimento das células. 2013. Disponível em: <http:// www.bbc.co.uk/portuguese/noticias/2013/og/13o917_vida_saudavel_enve lhecimento_celulas_lgb. shtml>. Acesso em: o1 mar. 2015 .

Descartes, R. Discours de la méthode. In: Adam, G. \& Tannery, P. (Ed.). Oeuvres de Descartes. Paris: Vrin, Centre National du Livre, 1996. v. 6, p. 1-78.

Euias, N. A solidão dos moribundos. Rio de Janeiro: Zahar, 1982. 
Fressoz, J. B. L'apocalypse joyeuse. Une histoire du risque technologique. Paris: Seuil, 2012.

Giacoia, O. J. Hans Jonas: por que a técnica moderna é um objeto para a ética. Natureza Humana, 1, 2, p. 4.07-20, 1999 .

Giglioni, G. The hidden life of matter: techniques for prolonging life in the writings of Francis Bacon. In: Solomon, J. R. \& Martin, G. G. (Ed.). Francis Bacon and the refiguring of early modern thought. Vermont: Ashgate, 2005. p. 129-44.

Hipócrates. Nature of man. In: Jones, W. H. S. (Ed.). Hippocrates. Cambridge: Harvard University Press, 1943. p. 1-592.

Gruman, G. A history of ideas about the prolongation of life. New York: Springer, 2003.

JACKSON, M. R. The prolongation of life in early modern english literature and culture, with emphasis on Francis Bacon. Chappel Hill, 2012. Tese (Doutorado em Literatura). Departamento de Literatura, University of North Caroline.

Jonas, H. O princípio de responsabilidade, ensaio de uma ética para a civilização tecnológica. Rio de Janeiro: Contraponto, 1979 .

Jones, W. H. S. (Ed.). Hippocrates. Cambridge: Harvard University Press, 1943.

Mikkeli, H. Hygiene in the early modern medical tradition. Helsinki: Academia ScientariumFennica, 1999.

Rees, G. (Ed.). The Oxford Francis Bacon. Oxford/New York: Oxford University Press, 1996-2007. 15 v.

ReEs, G. Preface. In: (Ed.). The Oxford Francis Bacon. Oxford/New York: Oxford University Press, 2007. v. 12, p. xlvi-lviii.

Rossi, P. Os filósofos e as máquinas. São Paulo: Companhia das Letras, 1989.

Silver, M. L. Remaking Eden: how genetic engineering and cloning will transform the american family (Ecco). New York: Harper Perennial, 2007.

Solomon, J. R. \& Martin, G. G. (Ed.). Francis Bacon and the refiguring of early modern though. Vermont: Ashgate, 2005.

Spedding, J.; Leslie R. \& Heath, D. D. (Ed.). The works of Francis Bacon. Stuttgart/Bad-Cannstatt: Frommann/Holzboog, 1963.

Zaterka, L. A longevidade segundo a concepção de vida de Francis Bacon. Filosofia e História da Biologia, 5,1, p. $127-4,0,2010$.

. As teorias da matéria de Francis Bacon e Robert Boyle: forma, textura e atividade. Scientiae Studia,10, 4, p. 681-709, 2012. 